\title{
Prognostic value of the preoperative lymphocyte-to-monocyte ratio for survival after lung cancer surgery
}

Ricard Ramos ${ }^{1,6^{*}}$, Ivan Macía ${ }^{1,6}$, Arturo Navarro-Martin² , Carlos Déniz ${ }^{1}$, Francisco Rivas ${ }^{1}$, Anna Ureña Cristina Masuet-Aumatell ${ }^{3}$, Camilo Moreno ${ }^{1}$, Ernest Nadal ${ }^{4,5}$ and Ignacio Escobar ${ }^{1}$

\begin{abstract}
Background: The aim of this study was to assess the effect of the lymphocyte-to-monocyte ratio (LMR), neutrophilto-lymphocyte ratio and platelet-to-lymphocyte ratio on overall survival and disease-free survival in patients with lung cancer treated with radical surgery.

Methods: We performed a retrospective review of patients with lung cancer who prospectively underwent radical resection between 2004 and 2012. Blood samples were taken as part of the preoperative workup. The inflammatory markers studied were absolute values of lymphocytes, monocytes, neutrophils and platelets, with subsequent calculation of ratios. Median follow-up was 52 months.

Results: Two hundred and sixty-eight patients underwent surgery, of whom 218 (81.3\%) were men. Mean age was $62.9 \pm 8.7$ years. A lymphocyte-to-monocyte ratio $\geq 2.5$ was independently associated with longer disease-free survival (hazard ratio [HR] $0.476(0.307-0.738), p=0.001)$ and longer overall survival (HR, $0.546 ; 95 \%$ Cl: 0.352-0.846; $p=0.007$ ), in models adjusted for age, sex, stage, and type of resection. No other systemic inflammatory marker showed a significant association.
\end{abstract}

Conclusion: Preoperative LMR is an independent prognostic factor of overall survival and recurrence-free survival in patients with surgically-resected early stage lung cancer.

Keywords: Inflammation, Lung cancer, Survival, Lymphocyte-to-monocyte ratio, Neutrophil-to-lymphocyte ratio, Platelet-to-lymphocyte ratio

\section{Background}

Lung cancer causes the most cancer-related deaths worldwide. Increasing knowledge of tumour biology and multimodal treatments have helped improve treatment, and several prognostic factors exist, but overall survival remains poor, except in stage I, for which survival ranges between 60 and $80 \%[1,2]$.

\footnotetext{
*Correspondence: ricardramos@ub.edu

${ }^{1}$ Department of Thoracic Surgery, Hospital Universitari de Bellvitge, Bellvitge Biomedical Research Institute (IDIBELL), Feixa Llarga s/n., 08907 L'Hospitalet de Llobregat, Barcelona, Spain

Full list of author information is available at the end of the article
}

Prognostic factors related not to the tumour itself but to the patient's general health status have been studied, including nutritional status and inflammatory status. Nutritional status is a prognostic factor in patients with lung cancer $[3,4]$, and our group has confirmed that nutritional status affects survival and postoperative outcomes in patients with lung cancer who undergo surgical resection [5].

Another prognostic factor that has been associated with survival and complications is inflammatory status. Multiple parameters can be used to determine the inflammatory status of a patient with cancer, but blood

(c) The Author(s) 2021. Open Access This article is licensed under a Creative Commons Attribution 4.0 International License, which permits use, sharing, adaptation, distribution and reproduction in any medium or format, as long as you give appropriate credit to the original author(s) and the source, provide a link to the Creative Commons licence, and indicate if changes were made. The images or other third party material in this article are included in the article's Creative Commons licence, unless indicated otherwise in a credit line to the material. If material is not included in the article's Creative Commons licence and your intended use is not permitted by statutory regulation or exceeds the permitted use, you will need to obtain permission directly from the copyright holder. To view a copy of this licence, visit http://creativecommons.org/licenses/by/4.0/. The Creative Commons Public Domain Dedication waiver (http://creativeco mmons.org/publicdomain/zero/1.0/) applies to the data made available in this article, unless otherwise stated in a credit line to the data. 
markers that are often used in preoperative assessment due to being simple to obtain are $\mathrm{C}$ reactive protein, absolute values of neutrophils, lymphocytes, monocytes and platelets, and the ratios of neutrophils to lymphocytes, platelets to lymphocytes and lymphocytes to monocytes. Certain levels of these parameters are associated with better or worse survival in various cancers, including lung cancer $[6,7]$.

The European Lung Cancer Working Group confirmed that patients with a high neutrophil count had worse survival [8]. Likewise, a high neutrophil-to-lymphocyte ratio and platelet-to-lymphocyte ratio are markers of worse prognosis in patients with cancer in general and particularly in lung cancer $[9,10]$; however, within the inflammatory response, lymphocytes and monocytes both play an important role in postoperative outcomes following lung cancer resection $[11,12]$.

In this study, we assessed the effect of these systemic inflammatory markers on overall survival (OS) and disease-free survival (DFS) in patients with non-small cell lung cancer (NSCLC) who underwent radical resection with follow-up of at least 5 years.

\section{Methods}

\section{Study population}

We retrospectively reviewed a cohort of 653 patients who were treated with radical lung resection between January 2004 and December 2012. Patients with a history of systemic inflammatory disease, concomitant active infection, neoadjuvant treatment, preoperative stage $\geq \mathrm{T} 3$, preoperative stage $\geq \mathrm{N} 1$, patients lost to follow-up, or those for whom preoperative blood tests were not available were excluded (Fig. 1). Finally, we included 268 patients diagnosed with early clinical stage non-small cell lung cancer who underwent anatomic pulmonary resection with systematic lymph node dissection.

All patients underwent the same preoperative workup which included physical examination, full blood count and renal function tests, bronchoscopy, pulmonary function tests with diffusion studies, computed tomography (CT) and positron-emission tomography/computed tomography (PET-CT). All patients signed an informed consent form and the study was approved by the Institutional Review Board.

\section{Study variables}

The variables studied were age, sex, comorbidities (smoking, diabetes mellitus, ischaemic heart disease, chronic obstructive pulmonary disease, and hypertension), type of surgery performed, pathological stage, tumour histology, disease-free survival and overall survival. The study aims did not include the association between these markers and postoperative complications.

The lymphocyte-to-monocyte ratio (LMR), neutrophilto-lymphocyte ratio (NLR), and platelet-to-lymphocyte ratio (PLR) were calculated from the absolute neutrophil, platelet, monocyte and lymphocyte counts from routine preoperative testing performed $1-2$ weeks before surgery at the same hospital.

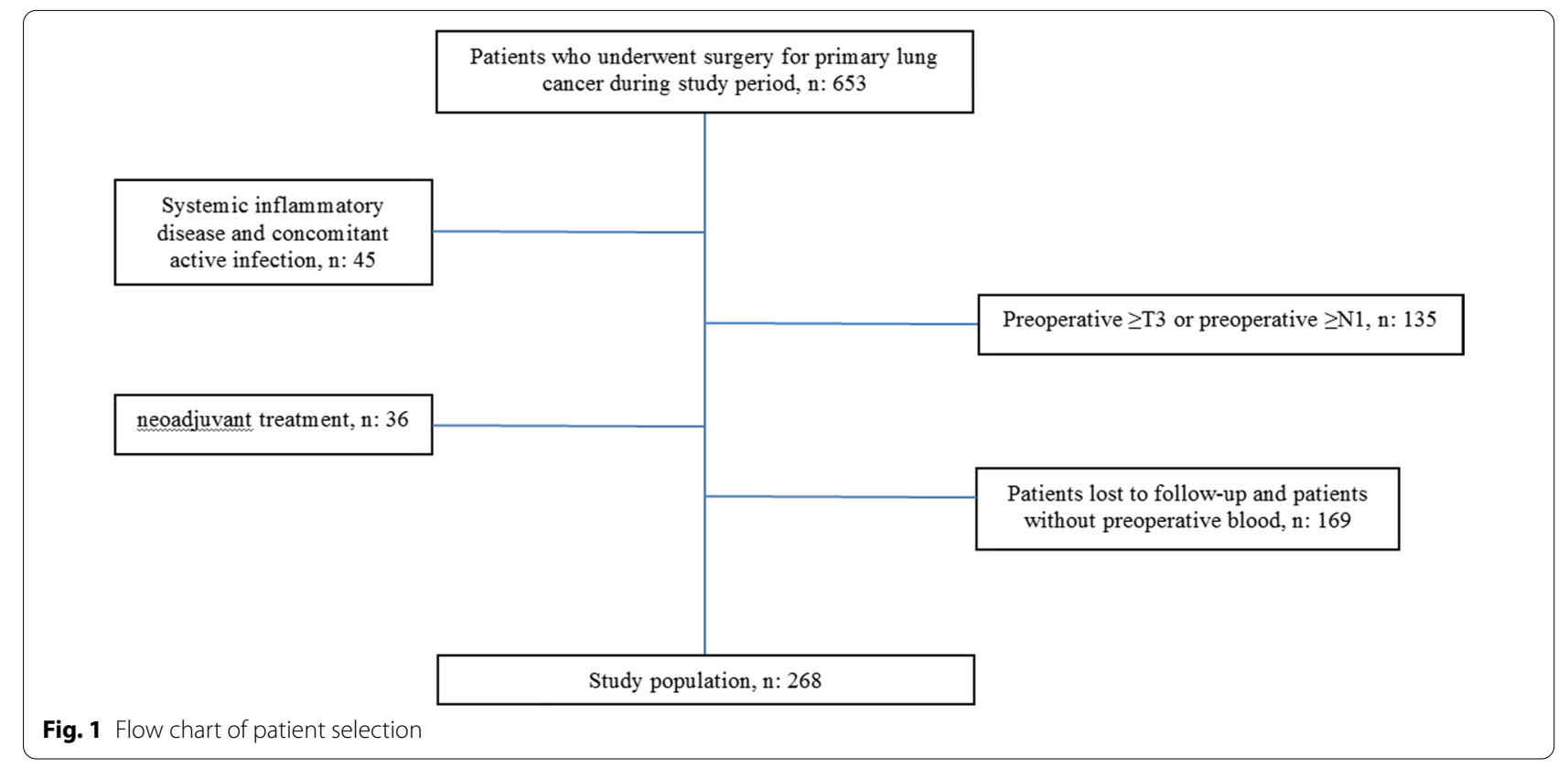




\section{Follow-up}

Routine follow-up was carried out at 1 month after surgery and included a full panel of blood tests and chest $\mathrm{X}$-ray, then every 6 months with CT chest for the first 3 years, with annual checks thereafter, as per hospital protocol. If recurrence was suspected after surgery, the relevant tests, eg PET-CT, MRI brain, were requested according to the clinical scenario. Recurrences were classified as locoregional or distant metastases based on imaging. Locoregional recurrence was defined as recurrence in mediastinal or hilar lymph nodes or ipsilateral lung. Other recurrences were defined as distant metastases. All patients were seen by specialists and discussed by the multidisciplinary team to decide on treatment planning. Diagnosis of recurrence or distant metastases was evaluated and confirmed in the multidisciplinary unit.

\section{Statistical analysis}

A descriptive analysis of the sample was performed as frequency and percentage for qualitative variables, and mean and standard deviation for quantitative variables if they followed a normal distribution (KolmogorovSmirnov, $p$ value $>0.05$ ), or median and interquartile range if not. Subsequently, Kaplan-Meier survival analysis was performed, and variables that were clinically relevant and statistically significant ( $\log$ rank $p$ value $<0.05$ ) and that did not show interaction between them were included in Cox regression. A receiver operating characteristics (ROC) analysis was performed to calculate the NLR, PLR, and LMR values that would have the greatest sensitivity and specificity. The statistical software SPSS v 16.0 was used.

\section{Results}

Two hundred and sixty-eight patients were included in the study, of whom 218 (81.3\%) were men. The mean age was $62.9 \pm 8.7$ years. Clinical, surgical, and pathological features and blood values of the study population are shown in Table 1 . Twenty-five patients $(9.2 \%)$ received tumour-specific adjuvant treatment. The median followup time was 52 months. One hundred patients (37.3\%) developed recurrence, of whom 74 (27.6\%) had distant metastases and 26 (9.7\%) had locoregional recurrence. Twelve patients $(4.5 \%)$ developed second primary lung tumours and underwent new radical surgery. One hundred and fifty-nine $(57.3 \%)$ patients were still alive at the end of follow-up; 109 (42.7\%) patients died.

Following ROC analysis, the values with the greatest sensitivity and specificity were 2.5 for NLR and LMR and 150 for PLR. Disease-free survival and OS were evaluated after splitting patients according to these proposed maker levels (Table 2). An LMR $\geq 2.5$ was a clear prognostic factor for higher overall survival and lower
Table 1 Clinical, surgical, pathological and inflammatory parameters for the study population

\begin{tabular}{ll}
\hline & N (\%) or mean \pm SD \\
& or median (range) \\
\hline Males & $268(81.3 \%)$ \\
Age (years) & $62.9 \pm 8.7$ \\
Smoker & $205(76.5 \%)$ \\
Diabetes mellitus & $57(21.3 \%)$ \\
Ischaemic cardiomyopathy & $33(12.3 \%)$ \\
COPD & $100(37.3 \%)$ \\
Hypertension & $103(38.4 \%)$ \\
Dyslipidaemia & $99(36.9 \%)$ \\
Surgical procedure & \\
Lobectomy & $224(83.6 \%)$ \\
Pneumonectomy & $14(5.2 \%)$ \\
Sub-lobar resection & $38(11.2 \%)$ \\
Pathologic stage & \\
la/lb & $173(64.5 \%)$ \\
Ila/Ilb & $74(27.6 \%)$ \\
Illa/lllb & $19(7.1 \%)$ \\
IV & $2(0.8 \%)$ \\
Histological type & \\
Adenocarcinoma & $168(62.7 \%)$ \\
Squamous cell carcinoma & $79(29.5 \%)$ \\
Large cell carcinoma & $18(6.7 \%)$ \\
Other & $3(1.1 \%)$ \\
Neutrophils, $\times 10^{9} / L$ & $4.47(1.63)$ \\
Lymphocytes, $\times 10^{9} / L$ & $2.14(1.59)$ \\
Monocytes, $\times 10^{9} / L$ & $0.57(0.20)$ \\
Platelets, $\times 10^{9} / L$ & $243(79.71)$ \\
LMR & $3.97(1.97)$ \\
NLR & $2.38(1.23)$ \\
\hline COR & $131.59(65.03)$ \\
\hline
\end{tabular}

COPD chronic obstructive pulmonary disease, $L M R$ lymphocyte-to-monocyte ratio, NLR neutrophil-to-lymphocyte ratio, $P L R$ platelet-to-lymphocyte ratio

Table 2 Distribution of patients according to LMR

\begin{tabular}{lll}
\hline Study population, n: 268 & $L M R<2.5$ & $L M R \geq 2.5$ \\
\hline $\begin{array}{l}\text { No. of patients } \\
\begin{array}{l}\text { No. of patients who died during the follow-up } \\
\text { period }\end{array}\end{array}$ & 28 & 221 \\
$\begin{array}{l}\text { No. of patients who died or had recurrence dur- } \\
\text { ing the follow-up period }\end{array}$ & 35 & 107 \\
\hline
\end{tabular}

LMR lymphocyte-to-monocyte ratio

recurrence in patients with surgically-resected lung cancer $(p=0.001)$ (Figs. 2, 3). On univariate analysis, age, pathological stage and LMR $\geq 2.5$ were significantly associated with higher disease-free survival (HR, 0.444; 95\% 


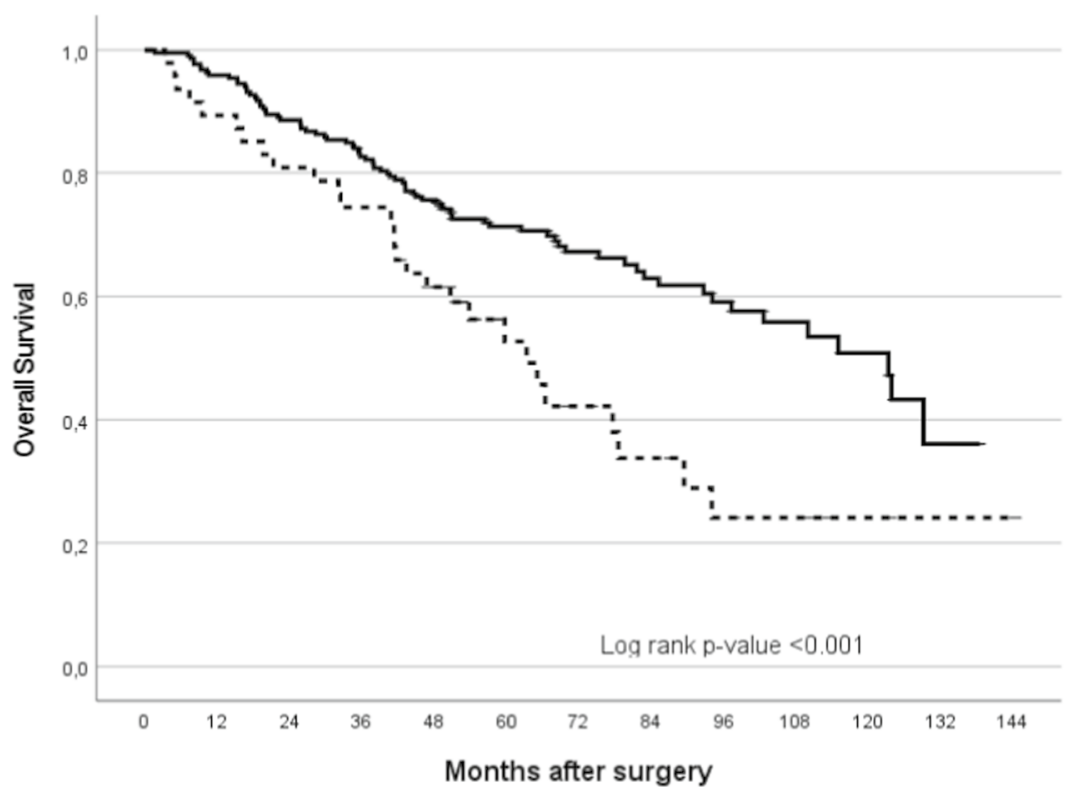

LMR $<2,5$

$-\cdot \cdot<2,50$

$->=2,50$

\begin{tabular}{|c|c|c|c|c|c|c|c|c|c|c|c|c|c|c|}
\hline & & 0 & 12 & 24 & 36 & 48 & 60 & 72 & 84 & 96 & 108 & 120 & 132 & 144 \\
\hline \multirow{3}{*}{$\mathrm{LMR}<2,5$} & $\%$ & & $89.4 \%$ & $80.9 \%$ & $74.5 \%$ & $61.6 \%$ & $52.8 \%$ & $42.2 \%$ & $33.8 \%$ & $24.1 \%$ & $24.1 \%$ & $24.1 \%$ & $24.1 \%$ & $24.1 \%$ \\
\hline & No of & 0 & 5 & 9 & 12 & 18 & 21 & 24 & 26 & 28 & 28 & 28 & 28 & 28 \\
\hline & No at & 47 & 42 & 38 & 35 & 27 & 15 & 11 & 8 & 5 & 4 & 2 & 1 & 1 \\
\hline \multirow[t]{4}{*}{$\mathrm{LMR}>=2,5$} & $\%$ & & $95.9 \%$ & $88.6 \%$ & $82.6 \%$ & $75.7 \%$ & $71.4 \%$ & $67.3 \%$ & $63.0 \%$ & $59.1 \%$ & $55.9 \%$ & $50.9 \%$ & $36.1 \%$ & --- \\
\hline & No of & & 9 & 25 & 38 & 53 & 61 & 66 & 70 & 73 & 75 & 77 & 80 & --- \\
\hline & No at & 219 & 210 & 193 & 179 & 156 & 107 & 73 & 57 & 41 & 24 & 15 & 5 & --- \\
\hline & risk & & & & & & & & & & & & & \\
\hline
\end{tabular}

Fig. 2 Kaplan-Meier analysis of overall survival (OS) based on LMR

CI $0.289-0.683 ; p=0.001)$. These variables remained statistically significant on multivariate analysis (HR, 0.476; 95\% CI 0.307-0.738; $p=0.001$; Table 3) after adjusting for age, sex, pathological stage and histology.

Regarding overall survival, univariate analysis showed that age, pathological stage and $L M R \geq 2.5$ were associated with better overall survival (HR, 0.488; 95\% CI $0.317-0.751 ; p=0.001)$. These variables were also significant on multivariate analysis (HR, 0.546; 95\% CI $0.352-0.846$; $p=0.007$; Table 4) after adjusting for age, sex, pathological stage and histology. NLR and PLR were not found to be prognostic factors for overall survival or disease-free survival. 


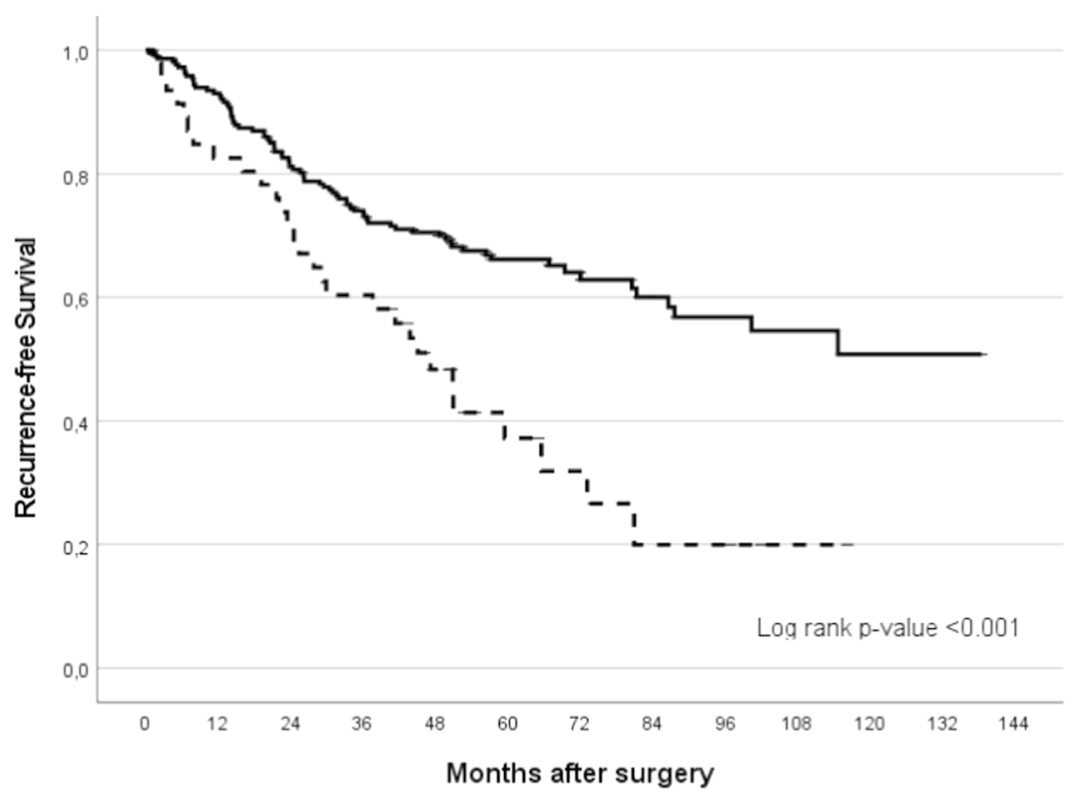

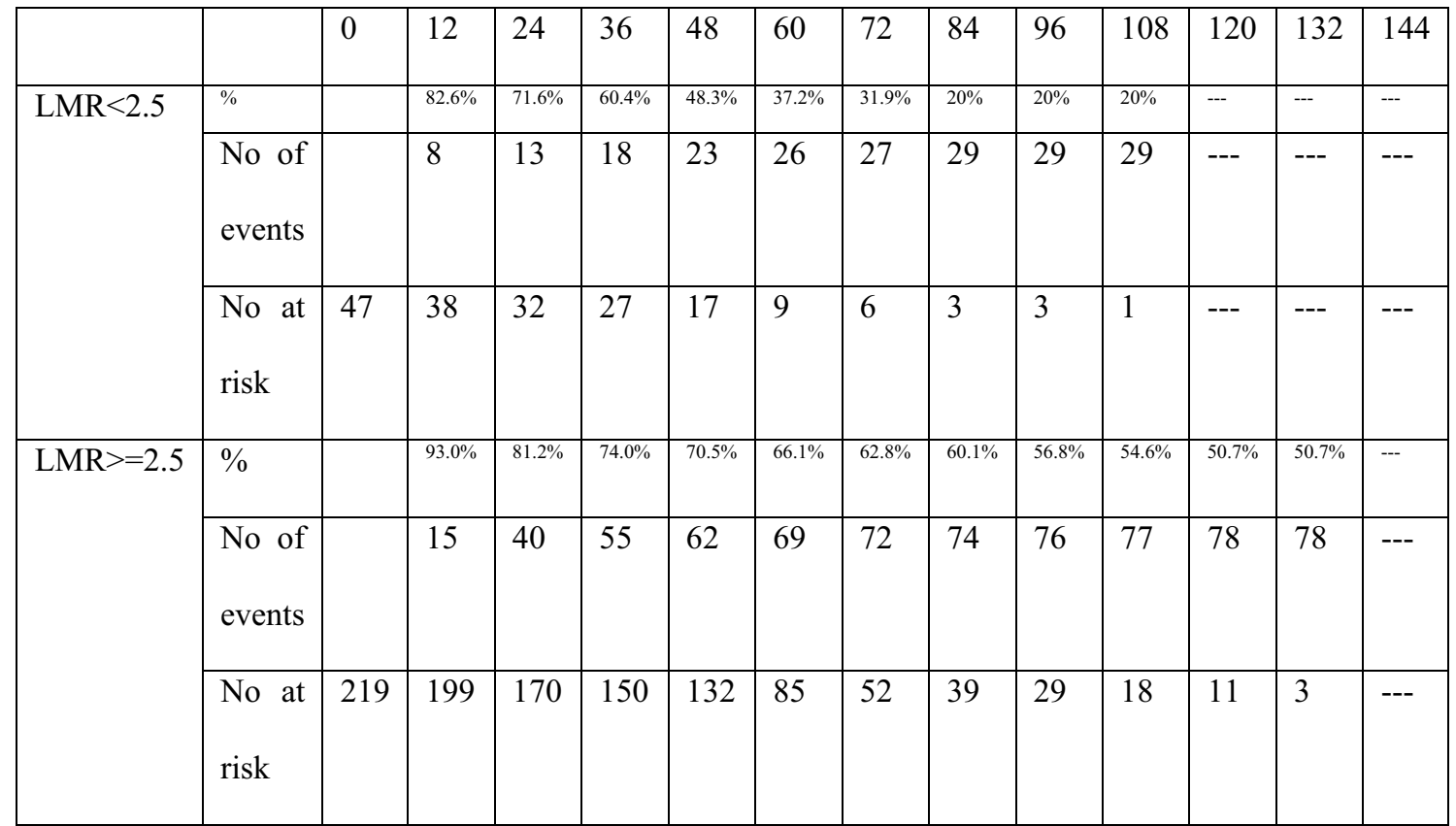

Fig. 3 Kaplan-Meier analysis of disease-free survival (DFS) based on LMR

\section{Discussion}

The association between inflammation and cancer was first described years ago and has been the subject of much study. O'Callaghan et al. [13] described the role of inflammation in the etiopathogenesis of lung cancer, and multiple studies have confirmed the prognostic value of inflammation in lung cancer outcomes, for both local and advanced disease $[10,14]$.
Our study included 268 patients who underwent resection and prospective follow-up for at least 5 years, and demonstrates that an $\mathrm{LMR} \geq 2.5$ is an independent positive prognostic factor for disease-free survival and overall survival. Although this ratio has not been studied extensively in cancer and particularly bronchogenic cancer, our findings are in line with those obtained by other groups. Xia et al. [15], in 439 patients with stage I 
Table 3 Univariate and multivariate analysis of disease-freesurvival (DFS)

\begin{tabular}{|c|c|c|c|}
\hline Covariables & Hazard ratio & $95 \% \mathrm{Cl}$ & $p$ value \\
\hline \multicolumn{4}{|l|}{ Univariate analysis } \\
\hline$P L R \geq 150$ & 0.986 & $0.654-1.488$ & 0.948 \\
\hline$N L R \geq 2.5$ & 1.203 & $0.821-1.761$ & 0.343 \\
\hline$L M R \geq 2.5$ & 0.444 & $0.289-0.683$ & 0.001 \\
\hline Age & 1.018 & $0.996-1.040$ & 0.112 \\
\hline Sex (female) & 0.970 & $0.595-1.579$ & 0.901 \\
\hline Pathological stage & & & $0.051^{*}$ \\
\hline 1 & 1.000 & & \\
\hline$\|$ & 1.686 & $1.126-2.526$ & 0.011 \\
\hline III & 1.793 & $0.812-3.958$ & 0.148 \\
\hline IV & 2.536 & $0.350-18.380$ & 0.357 \\
\hline Histological type & & & $0.219^{*}$ \\
\hline Adenocarcinoma & 1.000 & & \\
\hline Squamous cell carcinoma & 0.618 & $0.384-0.995$ & 0.048 \\
\hline Large cell carcinoma & 0.792 & $0.381-1.646$ & 0.532 \\
\hline Other & 0.568 & $0.138-2.343$ & 0.434 \\
\hline \multicolumn{4}{|l|}{ Multivariate analysis } \\
\hline$L M R \geq 2.5$ & 0.476 & $0.307-0.738$ & 0.001 \\
\hline Age & 1.029 & $1.005-1.054$ & 0.017 \\
\hline \multicolumn{4}{|l|}{ Sex } \\
\hline Male & 1.000 & & \\
\hline Female & 1.171 & $0.693-1.977$ & 0.556 \\
\hline Pathological stage & & & $0.027^{*}$ \\
\hline I & 1.000 & & \\
\hline$\|$ & 1.779 & $1.174-2.695$ & 0.007 \\
\hline III & 1.878 & $0.848-4.162$ & 0.120 \\
\hline IV & 3.101 & $0.406-23.695$ & 0.275 \\
\hline Histological type & & & $0.053^{*}$ \\
\hline Adenocarcinoma & 1.000 & & \\
\hline Squamous cell carcinoma & 0.527 & $0.322-0.862$ & 0.011 \\
\hline Large cell carcinoma & 0.619 & $0.294-1.301$ & 0.205 \\
\hline Other & 0.541 & $0.127-2.306$ & 0.407 \\
\hline
\end{tabular}

LMR lymphocyte-to-monocyte ratio, NLR neutrophil-to-lymphocyte ratio, PLR platelet-to-lymphocyte ratio

* Linear trend $p$ value

NSCLC, demonstrated a positive association between LMR and overall survival and a greater risk of distal metastases with lower LMR. However, Asian populations may behave differently from European populations in terms of blood markers, so their results will need to be validated in a Western population.

In 2018, Chen et al. [16] published a series of 577 surgical patients in stage IB NSCLC who had undergone pneumonectomy. They found that LMR and PLR were independent prognostic factors for OS. In our series, LMR was an independent prognostic factor for OS and DFS. However, we did not find a statistically significant
Table 4 Univariate and multivariate analysis of overall survival

\begin{tabular}{|c|c|c|c|}
\hline Covariables & Hazard ratio & $95 \% \mathrm{Cl}$ & $p$ value \\
\hline \multicolumn{4}{|l|}{ Univariate analysis } \\
\hline$P L R \geq 150$ & 1.151 & $0.772-1.715$ & 0.494 \\
\hline$N L R \geq 2.5$ & 1.175 & $0.806-1.714$ & 0.401 \\
\hline$L M R \geq 2.5$ & 0.488 & $0.317-0.751$ & 0.001 \\
\hline Age & 1.037 & $1.013-1.060$ & 0.002 \\
\hline Sex (female) & 0.831 & $0.481-1.436$ & 0.507 \\
\hline Pathological stage & & & $0.026^{*}$ \\
\hline Stage I & 1.000 & & \\
\hline Stage II & 1.718 & $1.148-2.571$ & 0.009 \\
\hline Stage III & 1.980 & $0.975-4.017$ & 0.059 \\
\hline Stage IV & 2.296 & $0.317-16.631$ & 0.411 \\
\hline Histological type & & & $0.999^{*}$ \\
\hline Adenocarcinoma & 1.000 & & \\
\hline Squamous cell carcinoma & 0.991 & $0.651-1.509$ & 0.967 \\
\hline Large cell carcinoma & 1.041 & $0.518-2.091$ & 0.909 \\
\hline Other & 0.986 & $0.135-7.190$ & 0.989 \\
\hline \multicolumn{4}{|l|}{ Multivariate analysis } \\
\hline$L M R \geq 2.5$ & 0.546 & $0.352-0.846$ & 0.007 \\
\hline Age & 1.041 & $1.017-1.066$ & 0.001 \\
\hline \multicolumn{4}{|l|}{ Sex } \\
\hline Male & 1.000 & & 0.966 \\
\hline Female & 1.013 & $0.564-1.819$ & \\
\hline Pathological stage & & & $0.013^{*}$ \\
\hline 1 & 1.000 & & \\
\hline$\|$ & 1.783 & $1.179-2.697$ & 0.006 \\
\hline III & 2.144 & $1.047-4.389$ & 0.037 \\
\hline IV & 4.083 & $0.521-31.995$ & 0.180 \\
\hline Histological type & & & $0.830^{*}$ \\
\hline Adenocarcinoma & 1.000 & & \\
\hline Squamous cell carcinoma & 0.812 & $0.525-1.255$ & 0.348 \\
\hline Large cell carcinoma & 0.923 & $0.457-1.864$ & 0.824 \\
\hline Other & 0.929 & $0.122-7.056$ & 0.943 \\
\hline
\end{tabular}

$L M R$ lymphocyte-to-monocyte ratio, NLR neutrophil-to-lymphocyte ratio, $P L R$ platelet-to-lymphocyte ratio

* Linear trend $p$ value

association for PLR as a prognostic factor. One explanation could be that the patients requiring pneumonectomy are usually patients with larger tumours or with greater intrapulmonary lymph node involvement, so they are likely to have higher baseline levels of inflammation. In our study only $5.2 \%$ of the patients had undergone pneumonectomy, while $100 \%$ of those in the study by Chen et al. had undergone pneumonectomy, with pleural invasion in $39 \%$ of the cases.

The immunological basis for our findings is that lymphoid cells play a primordial role in the control, proliferation, and migration of tumour cells [17]. In cervical cancer, it has been observed that lymphocytes act as 
essential components of the immune response, and low levels of lymphocytes in the peripheral blood and tumour stroma lead to a weaker immune response against the cancer cell [18]. In contrast, the presence of high levels of monocytes and their derivatives induces immunosuppression and tumour neoangiogenesis. In addition, intratumour macrophages, derived directly from tissue monocytes, facilitate tumour cell migration by secreting mediators that degrade the extracellular matrix and attract more intratumour monocytes/macrophages, leading to greater tumour aggressiveness both locally and distally [19-22].

In nonsurgical treatments such as stereotactic radiation therapy, several groups have described the effect of NLR and PLR in terms of local recurrence. Canon et al. [10] found that PLR should be used as a prognostic factor for DFS. In our study, we did not find such an association, but we must bear in mind that the inflammatory status in the nonsurgical population is probably different: although in some cases patients decline surgery, in many cases they are unsuitable for surgery due to comorbidities.

The interaction between nutritional status, systemic inflammatory status and tumour inflammatory status plays a key role in postoperative outcomes and prognosis in patients with lung cancer [23]. This explains why a higher or lower LMR confers better or worse disease prognosis among patients undergoing surgery, who theoretically will have better long-term outcomes.

The present study has the limitations of being a singlecentre retrospective study. Also, although the preoperative testing used to obtain the ratios was the same for all patients, the findings have not been validated in an independent cohort. The ideal cut-off point for the ratio is difficult to establish, but according to our results, the value with the greatest sensitivity and specificity was 2.5 ; values above or below this showed significant differences in overall survival and disease-free survival, in line with other published studies [15-17, 24, 25].

The number of patients included, more than 200, the consistency of the blood testing method, the follow-up time and the prospective format of data recording make the data presented relevant for future research.

\section{Conclusions}

The findings from this study in a cohort of patients who underwent surgery for NSCLC confirm that the lymphocyte-to-monocyte ratio is a convenient preoperative biomarker that could provide valuable information on the probability of recurrence and overall survival in this population.

\section{Abbreviations}

LMR: Lymphocyte-to-monocyte ratio; NLR: Neutrophil-to-lymphocyte ratio; PLR: Platelet-to-lymphocyte ratio; OS: Overall survival; DFS: Disease-free survival; HR: Hazard ratio; NSCLC: Non-small cell lung cancer; CT: Computed tomography; PET-CT: Positron-emission tomography/computed tomography; ROC: Receiver operating characteristics.

\section{Acknowledgements}

Not applicable.

\section{Authors' contributions}

$R R$ and EN made substantial contributions to the design of this study; RR, IM, $C D, F R, A U, C M a$, and IE collected and analysed the data; RR, IM, ANM, CD, FR, $\mathrm{AU}, \mathrm{CMo}$ and IE wrote the manuscript; RR, revised the manuscript. All authors read and approved the final manuscript.

\section{Funding}

We received no external funding for this study.

\section{Availability of data and materials}

The datasets used and/or analysed during the current study are available from the corresponding author on reasonable request.

\section{Ethics approval and consent to participate}

All patients signed an informed consent form. The study was approved by the Clinical Research Ethics Committee of Bellvitge University Hospital (CEIC). All methods were carried out in accordance with relevant guidelines and regulations.

\section{Consent for publication}

Not applicable.

\section{Competing interests}

The authors declare that they have no conflict of interest.

\section{Author details}

${ }^{1}$ Department of Thoracic Surgery, Hospital Universitari de Bellvitge, Bellvitge Biomedical Research Institute (IDIBELL), Feixa Llarga s/n., 08907 L'Hospitalet de Llobregat, Barcelona, Spain. ${ }^{2}$ Department of Radiation Oncology, Catalan Institute of Oncology (ICO), Bellvitge Biomedical Research Institute (IDIBELL), L'Hospitalet de Llobregat, Barcelona, Spain. ${ }^{3}$ Department of Preventive Medicine. Hospital Universitari de Bellvitge, Bellvitge Biomedical Research Institute (IDIBELL), L'Hospitalet de Llobregat, Barcelona, Spain. ${ }^{4}$ Department of Medical Oncology, Catalan Institute of Oncology (ICO), L'Hospitalet de Llobregat, Barcelona, Spain. ${ }^{5}$ Clinical Research in Solid Tumors Group, OncoBell Program, Bellvitge Biomedical Research Institute (IDIBELL), L'Hospitalet de Llobregat, Barcelona, Spain. ${ }^{6}$ Unit of Human Anatomy, Department of Pathology and Experimental Therapeutics, Medical School, University of Barcelona, Barcelona, Spain.

Received: 2 December 2020 Accepted: 23 February 2021 Published online: 02 March 2021

\section{References}

1. De Angelis R, Sant M, Coleman MP, Francisci S, Baili P, Pierannunzio D, Trama A, Visser O, Brenner H, Ardanaz E, Bielska-Lasota M, Engholm G, Nennecke A, Siesling S, Berrino F, Capocaccia R, EUROCARE-5 Working Group. Cancer survival in Europe 1999-2007 by country and age: results of EUROCARE-5-a population-based study. Lancet Oncol. 2014;15(1):23-34

2. Custodio AB, González-Larriba JL, Bobokova J, Calles A, Alvarez R, Cuadrado E, Aranzazu M, Díaz-Rubio E. Prognostic and predictive markers of benefit from adjuvant chemotherapy in early-stage non-small cell lung cancer. J Thorac Oncol. 2009;4(7):891-910.

3. Sepesi B, Gold KA, Correa AM, Heymach JV, Vaporciyan AA, Roszik J, Dmitrovsky $E$, Liu X. The influence of body mass index on overall survival following surgical resection of non-small cell lung cancer. J Thorac Oncol. 2017;12(8):1280-7. 
4. Stone E, Slatore CG. The obesity paradox-what does it mean for lung cancer surgery? J Thorac Oncol. 2017;12(8):1174-6.

5. Ramos R, Nadal E, Peiró I, Masuet-Aumatell C, Macia I, Rivas F, Rosado G, Rodriguez P, Ureña A, Padrones S, Aso A, Deniz C, Navarro A, Escobar I. Preoperative nutritional status assessment predicts postoperative outcomes in patients with surgically resected non-small cell lung cancer. Eur J Surg Oncol. 2018;44(9):1419-24.

6. Shiels MS, Pfeiffer RM, Hildesheim A, Engels EA, Kemp TJ, Park JH, Hormuzd AK, Koshiol J, Shelton G, Caporaso N, Pinto LA, Chaturvedi A. Circulating inflammation markers and prospective risk for lung cancer. J Natl Cancer Inst. 2013;105(24):1871-80.

7. Lochowski M, Lochowska B, Zawadzka I, Cieślik-Wolski B, Kozik D, Kozak J. Prognostic value of neutrophil-to-lymphocyte, platelet-to-lymphocyte and lymphocyte-to-monocyte ratio ratios in patients operated on due to non-small cell lung cancer. JThorac Dis. 2019;11(8):3377-84.

8. Paesmans M, Sculier JP, Libert P, Bureau G, Dabouis G, Thiriaux J, et al. Prognostic factors for survival in advanced non-small-cell lung cancer: univariate and multivariate analyses including recursive partitioning and amalgamation algorithms in 1052 patients. The European Lung Cancer Working Party. J Clin Oncol. 1995:13:1221-30.

9. Okamura Y, Sugiura T, Ito T, Yamamoto Y, Ashida R, Mori K, Uesaka K. Neutrophil to lymphocyte ratio as an indicator of the malignant behavior of hepatocellular carcinoma. Br J Surg. 2016;103(7):891-8.

10. Cannon NA, Meyer J, lyengar P, Ahn C, Westover KD, Choy H, Timmerman R. Neutrophil-lymphocyte and platelet-lymphocyte ratios as prognostic factors after stereotactic radiation therapy for early-stage non-small-cell lung cancer. J Thorac Oncol. 2015;10(2):280-5.

11. Zhang J, Huang SH, Li H, Li Y, Chen XL, Zhang WQ, Chen HG, Gu L. Preoperative lymphocyte count is a favorable prognostic factor of disease-free survival in non-small cell lung cancer. Med Oncol. 2013;30:352.

12. Yuan C, Li N, Mao X, Liu Z, Ou W, Wang SY. Elevated pretreatment neutrophil/white blood cell ratio and monocyte/lymphocyte ratio predict poor survival in patients with curatively resected non-small cell lung cancer: results from a large cohort. Thorac Cancer. 2017;8(4):350-8.

13. O'Callaghan DS, O'Donnell D, O'Connell F, O'Byrne KJ. The role of inflammation in the pathogenesis of non-small cell lung cancer. JThorac Oncol. 2010;5(12):2024-36

14. Takahashi Y, Horio H, Hato T, Harada M, Matsutani N, Morita S, Kawamura M. Prognostic significance of preoperative neutrophil-lymphocyte ratios in patients with stage I non-small cell lung cancer after complete resection. Ann Surg Oncol. 2015;22:S1324-31.

15. Xia H, Sun Z, Deng L, Zhu D, Wang D. Prognostic significance of the preoperative lymphocyte to monocyte ratio in patients with stage I non-small cell lung cancer undergoing complete resection. Cancer Investig. 2016;34(8):378-84.

16. Chen Y, Wang W, Zhang X, Yu X, Xi K, Wen Y, Wang G, Feng X, Zhang L. Prognostic significance of combined preoperative platelet-to-lymphocyte ratio and lymphocyte-to-monocyte ratio in patients undergoing surgery with stage IB non-small-cell lung cancer. Cancer Manag Res. 2018:10:5411-22.

17. Hanahan D, Weinberg RA. Hallmarks of cancer: the next generation. Cell. 2011;144(5):646-74

18. Chen L, Zhang F, Sheng XG, Zhang SQ. Decreased pretreatment lymphocyte/monocyte ratio is associated with poor prognosis in stage Ib1-Ila cervical cancer patients who undergo radical surgery. Onco Targets Ther. 2015;8(8):1355-62.

19. Krstic J, Santibanez JF. Transforming growth factor-beta and matrix metalloproteinases: functional interactionsin tumor stromainfiltrating myeloid cells. Sci World J. 2014;2014:521754

20. Pollard JW. Tumour-educated macrophages promote tumour progression and metastasis. Nat Rev Cancer. 2004;4:71-8.

21. Sarode P, Schaefer MB, Grimminger F, Seeger W, Savai R. Macrophage and tumor cell cross-talk is fundamental for lung tumor progression: we need to talk. Front Oncol. 2020;10(324):1-11.

22. Feng F, Zheng G, Wang Q, Liu S, Liu Z, Xu G, Wang F, Guo M, Lian X, Zhang H. Low lymphocyte count and high monocyte count predicts poor prognosis of gastric cancer. BMC Gastroenterol. 2018;18(1):148.

23. Alifano M, Mansuet-Lupo A, Lococo F, Roche N, Bobbio A, Canny E, Schussler O, Dermine H, Régnard JF, Burroni B, Goc J, Biton J, Ouakrim H, Cremer I, Dieu-Nosjean MC, Damotte D. Systemic inflammation, nutritional status and tumor immune microenvironment determine outcome of resected non-small cell lung cancer. PLoS ONE. 2014;19(9):e106914.

24. Shoji F, Kozuma Y, Toyokawa G, Yamazaki K, Takeo S. Complete blood cell count-derived inflammatory biomarkers in early-stage non-small-cell lung cancer. Ann Thorac Cardiovasc Surg. 2020. https://doi.org/10.5761/ atcs.oa.19-00315.

25. Huang Q, Diao P, Li CL, Peng Q, Xie T, Tan Y, Lang JY. Preoperative plateletlymphocyte ratio is a superior prognostic biomarker to other systemic inflammatory response markers in non-small cell lung cancer. Medicine (Baltimore). 2020;99(4):e18607. https://doi.org/10.1097/MD.0000000000 018607.

\section{Publisher's Note}

Springer Nature remains neutral with regard to jurisdictional claims in published maps and institutional affiliations.
Ready to submit your research? Choose BMC and benefit from:

- fast, convenient online submission

- thorough peer review by experienced researchers in your field

- rapid publication on acceptance

- support for research data, including large and complex data types

- gold Open Access which fosters wider collaboration and increased citations

- maximum visibility for your research: over 100M website views per year

At BMC, research is always in progress.

Learn more biomedcentral.com/submissions 